\title{
Impact of Mass Media to Creates Awareness among the Poor Parents against Child Labor
}

\author{
Md. Farhad Hossain* \\ Department of Statistics, Comilla University, Cumilla, Bangladesh. \\ *Correspondence: farhad390ju@gmail.com (Md. Farhad Hossain, Assistant Professor, Department of Statistics, Comilla \\ University, Cumilla, Bangladesh).
}

\begin{abstract}
Child labor is a widespread phenomenon. It is globally known to be an aspect of child abuse. The present study discussed the impact of mass media to create awareness among poor parents against child labor. For this purpose, data were collected from parents of a child laborer, child laborer, and employers who recruited child labor from Cumilla districts. The findings revealed that male adolescents have been involved as child laborers compared to female adolescents. Downcast literacy rate observed of the parents of the child laborer. Sample characteristics indicated that child laborer belongs to a large family. Also, the study observed that the dropout rate is high for working children. Two of the greatest usual reasons for the kiddies to reasoning the job were poorness and careless outlook unto study as reported. The finding of that study will help our parents to be more conscious of their kids.
\end{abstract}

Keywords: Mass media, Adolescent, Child labor, Impact, Abolishing, Awareness, Cumilla, and Poor parents.

\section{INTRODUCTION:}

Concerns over the adverse effect of child labor are gradually increasing particularly from the commencement of the twentieth centenary. Now a day's infant fatigue is not considered an isolated issue but a thickened segment of national-international efforts for economic and social development. The Media has been ever used as an efficient cause of overthrowing consciousness in the masses. The Media has the force to touch close to all. Many communal scientists confide that mass media replay is necessary if patent attention for children's realism is to stay on the political procession, and if children safeguard worship are to keep responsible (Goddard \& Saunders, 2001). According to the International Labor Office (ILO) children work the longer times and are the scalp paid of all laborers (Bequele and Boyden 1988). BanglaUniversePG I www.universepg.com desh is an extremely replenished country in the world. It has 1, 44,498 square kilometers in total area and more than 140 million populations (Bangladesh Bureau of Statistics, 2011).

The people of Bangladesh, nearly $47 \%$ are beneath 16 years and $17 \%$ of the people are underneath 5 years of age. Child labor continues to be a fact in almost all parts of Bangladesh. A report from the UNESCO Institute of statistics on the Child labor situation in Bangladesh in 2016 explained that 4.3 percent of child labor (Age 5-14) exists in the performing population $(1,326,411)$ and combining employment and institute 1.9 percent respectively. According to National Child Labor Elimination Policy 2010; objective three emphasizes the awareness of parents- "Raising awareness amongst parents, mass people and civil 
societies about the pernicious consequences of child labor; and objective two also stated that-'Involving guardians of pursuit children in income-generating activities with a view of getting children out of the vicious circle of poverty".

Although the number of adolescent working throughout the realm is unknown, it is immensely large indeed and unquestionably in the hundreds of lakh. The extinct National Child Labor Survey report revealed that 1.2 million kiddies are only entangling in its scalp forms. Understanding media effects, and how to exercise the media constructively, can so be a necessary instrument for who solicitor for child, young people, and their families (Brawley 1995). The International Labor Organization's (ILO) Minimal Age Convention 138 narrated that a child of age 12 was accepted to futile labor in non-hazardous condition and a child of age 15 was accepted to drive the workforce (Schmitz et al., 2004). Its definition also explained that child labor is working that direction to deposition of childhood actions, occlusion, and misuse (UNICEF, 2010). Sub-Saharan Africa had the maximum span worth of child labor in 2010; with various African nations vouch for above $50 \%$ of kiddies old 514 pursuit (UNICEF, 2012). The basic root of child labor is poorness and absence of schools (ILO, United Nations, 2008). Different former research found that penury forces parents to repose their kiddies afar from school but main them to enter into the work (Jensen \& Nielsen, 1997). More than 5\% of the world's performing children are in Bangladesh (The Daily Star, 2011). Child laborer was 1.15 million in peasant areas and 0.29 million in civic areas and 0.25 million in City Corporation areas (NCLS, 2013; Sultana, 2020).

Government parties should ken the right of the children to be safe from monetary occlusion and from execution any employment that is apparently to be perilous or to trespass with the child's lesson, or could be worse for the child's corporal, psychic, or social progress (Paul, 2008). International Labor Organization (ILO) has been working for elimination of child labor in Bangladesh since 1994. There has been very limited research conducted about the media on human rights issues. This research aims to explore the preamble of mass media to creating awareness within unprivileged guardians versus child labor. All the UniversePG I www.universepg.com output is made by using different software such as SPSS 20.0 and Ms. Excel (Hossain et al., 2020).

\section{METHODOLOGY:}

\subsection{Study area}

The study was selected in Cumilla city as a study area. There are numerous factories, industries, garments, transports companies, restaurants, street hawkers, CNG conversion stations, bus terminals, railway stations, water port, street shops, and street food shops as well domestic child workers living here.

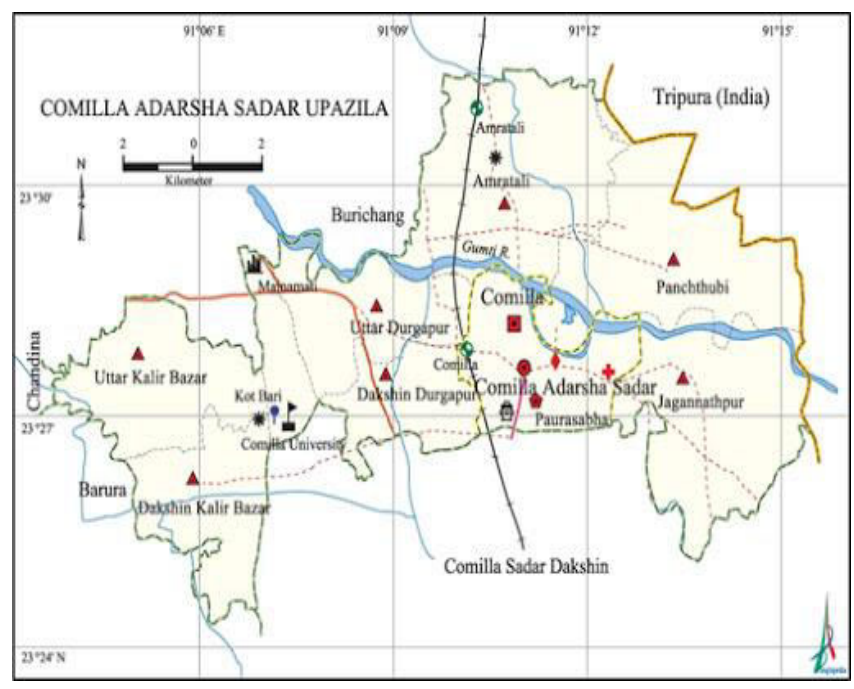

Fig 1: Cumilla Adarsha Sadar.

\subsection{Study population}

There are many districts' poor and marginal people living in Cumilla city. Poor parents, child laborer were included as the study population.

\subsection{Sampling Method and data collection tech- niques}

The sampling method was a convenience sampling in this study. Though it is less reliable, this method was conducted because for low cost and less time. We also were dispossessed of a perfect sampling frame. Also in a qualitative study what we have as a segment in our study, often it was not feasible to use probability sampling. So, our sample in this survey consists of respondents living in freely accessible locales and who were willing to respond. The data collection technique is interview, specially structured interview. The final data collection tool, a semi-structured questionnaire with close-ended questions, was developed phase by 
phase. At first, a primary questionnaire was developed based on the literature to understand the research. Finally, the questionnaire was modified and finalized for data collection in the field.

\subsection{Data analysis}

Data were analyzed by using qualitative manner (reasoning, thematic analysis, narrative, and verbatim), and survey information was analyzed by using simple and inferential statistical tools (Mean, Frequency distribution, Median, Standard Deviation, correlation) through SPSS software. Respondent's opinion also is included in this work. Different marginal computations such as frequency distribution, pie charts, bar diagrams are used to display the graphical scenario at a glance.

\section{RESULTS AND DISCUSSION:}

It is observed from Table $\mathbf{1}$ maximum of the child laborers are men. So, male adolescents are mostly engaged in child labor than female adolescents. The study explored that maximum of the child laborer fathers have no education and a small number of fathers are literate that is, $14.44 \%$ of fathers are literate and $85.56 \%$ of fathers are illiterate. The table also explored that, $27.78 \%$ Childs father is Farmer, $38.89 \%$ are daily workers, $13.33 \%$ doing small business, $7.78 \%$ are unoccupied and $12.22 \%$ have other occupations. It means that greater portion of the fathers is day laborers such as they are rickshaw puller, working in construction, light manufacturing, landscaping, and other similar jobs. Some of them are farmers, doing small business and some of them are unoccupied.

Table 1: Socio-demographic characteristics of the respondents

\begin{tabular}{cccc}
\hline & & \multicolumn{2}{c}{ Working group } \\
& & Numbers & Percent \\
\hline Gender of the child & Male & 74 & 82.22 \\
& Female & 16 & 17.78 \\
Fathers education & Illiterate & 77 & 85.56 \\
& Literate & 13 & 14.44 \\
Mothers education & Illiterate & 81 & 90.0 \\
& Literate & 9 & 10.0 \\
Fathers Occupation & Farmer & 25 & 27.78 \\
& Daily worker & 35 & 38.89 \\
& Small Business & 12 & 13.33 \\
& Unoccupied & 7 & 7.78 \\
& Others & 11 & 12.22 \\
Mothers Occupation & Housewife & 68 & 75.55 \\
& Others & 22 & 24.45 \\
Numbers of children & One & 00 & 00 \\
& Two & 22 & 24.45 \\
& Three & 41 & 45.55 \\
& Four & 27 & 30.0 \\
Fathers income level & No income & 15 & 16.67 \\
& $<=5000$ & 29 & 32.22 \\
& 5001-10000 & 24 & 26.67 \\
& $10001-15000$ & 12 & 13.33 \\
& $>=15001$ & 10 & 11.11 \\
Mothers income level & No income & 66 & 73.33 \\
& $<=3000$ & 16 & 17.78 \\
& $3001-5000$ & 8 & 8.89 \\
\hline
\end{tabular}

Table 1 also reveals that the maximum number of fathers' income lies less than 5000 taka's. Their income level is so weak to sustain the primary needs of their family. Also, it is observed that most of the working children mother has no education. Small numbers of mothers have primary education only in this survey. According to the survey it is observed that only $10 \%$ of mothers of the working children have 
their primary education and $90 \%$ of mothers are uneducated. So, maximum child laborers' mothers have no education.

The study reveals that $75.55 \%$ of mothers are housewives and $24.45 \%$ are doing other job. Maximum working children mother does not work outside, they are a housewife. Some of them are doing other jobs such as work as a housemaid, doing small business, etc. in our study. In conformity with the table, it is observed that maximum of the working children mothers have no income. They have no exploit in terms of family income. This survey also reveals that greater portion of the family is big and they have three and four children.

Table 2: Representing the number and percentage of Childs reason not for studying

\begin{tabular}{ccc}
\hline Reasons & Number & Percent \\
\hline Distance of school & 3 & 3.33 \\
To support family & 13 & 14.45 \\
For helping housework & 8 & 8.89 \\
Unwillingness of Parents & 12 & 13.33 \\
Unwillingness of Child & 11 & 12.22 \\
Unable to bear studying cost & 35 & 38.89 \\
Others & 8 & 8.89 \\
Total & 90 & 100.0 \\
\hline
\end{tabular}

Table 3: Representing the number and percentage of the child laborer according their working status

\begin{tabular}{ccc} 
Hour & Number & Percent \\
\hline $3-5$ & 15 & 16.67 \\
$6-8$ & 37 & 41.11 \\
$9-11$ & 21 & 23.33 \\
Others & 17 & 18.89 \\
Total & 90 & 100.0 \\
\hline
\end{tabular}

Table 4: Representing the number and percentage of respondent's opinion in terms of media role to create social awareness

\begin{tabular}{lcc}
\hline Opinion & Number & Percent \\
\hline Strongly disagree & 18 & 20.0 \\
Disagree & 35 & 38.89 \\
Neutral & 15 & 16.67 \\
Agree & 13 & 14.44 \\
Strongly agree & 09 & 10.0 \\
Total & 90 & 100.0 \\
\hline
\end{tabular}

Table 5: Satisfaction level of parents about the role of mass media to stop child labor

\begin{tabular}{ccc}
\hline Opinion & Number & Percent \\
\hline Strongly disagree & 11 & 12.22 \\
Disagree & 15 & 16.67 \\
Neutral & 36 & 40.0 \\
Agree & 16 & 17.78 \\
Strongly agree & 12 & 13.33 \\
Total & 90 & 100.0 \\
\hline
\end{tabular}


Table 6: Representing the number and percentages of most-viewed T.V. channels by the parents

\begin{tabular}{ccc}
\hline Responses & Number & Percent \\
\hline $\begin{array}{c}\text { Indian TV } \\
\text { channels }\end{array}$ & 11 & 12.22 \\
$\begin{array}{c}\text { Bangladeshi TV } \\
\text { (movie) channels }\end{array}$ & 46 & 51.11 \\
Game channel & 33 & 36.67 \\
Total & 90 & 100.0 \\
\hline
\end{tabular}

Table 2 explored that most of the working children (38.89) do not study because they are unable to afford the study costs. The remaining of them are do not study for the distance of the school (3.33), for helping housework (8.89), the unwillingness of the children (12.22), the unwillingness of parents (13.33), to support the family (14.45), and many other reasons (8.89). Table 3 explored that $16.67 \%$ Childs works $3-5$ hours during the day, $41.11 \%$ work $6-8$ hours, $23.33 \%$ work 9-11 hours and $18.89 \%$ Childs work much more from 9-11 hours per day.

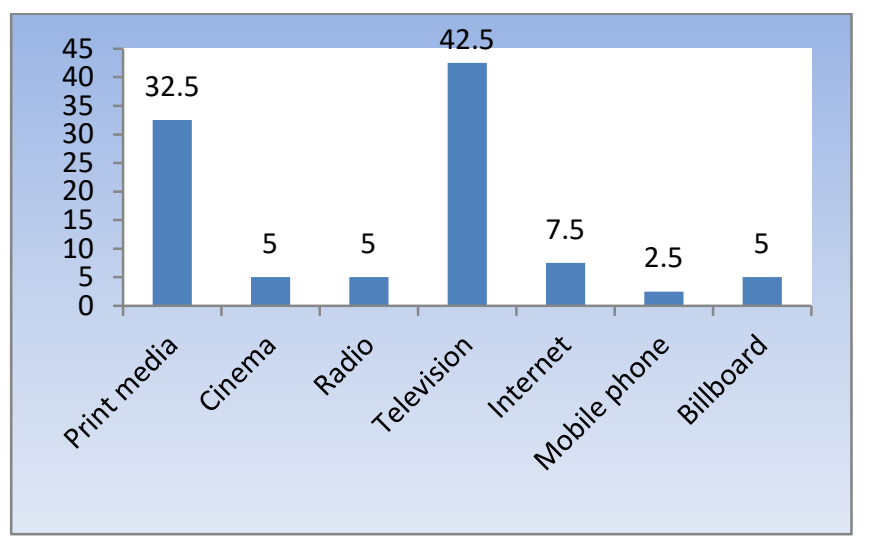

Fig 2: Representing the percentage of parent's knowledge about mass media.

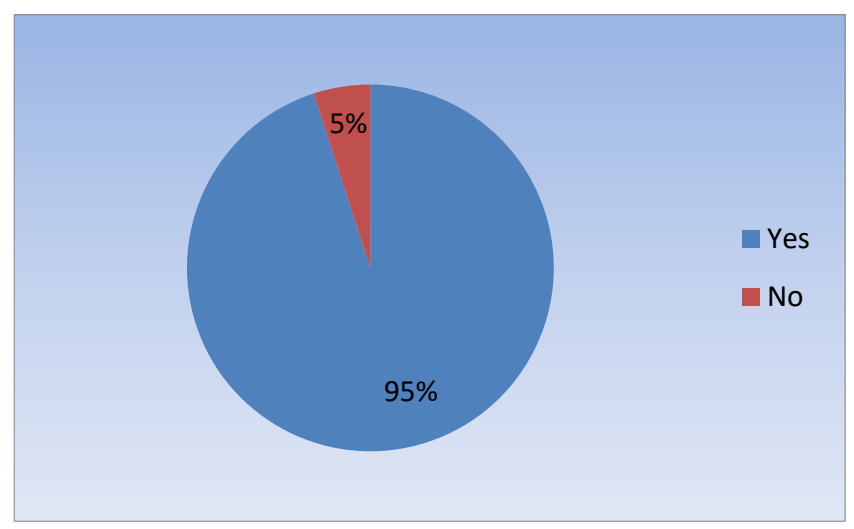

Fig 3: Respondent opinions to combat child labor.

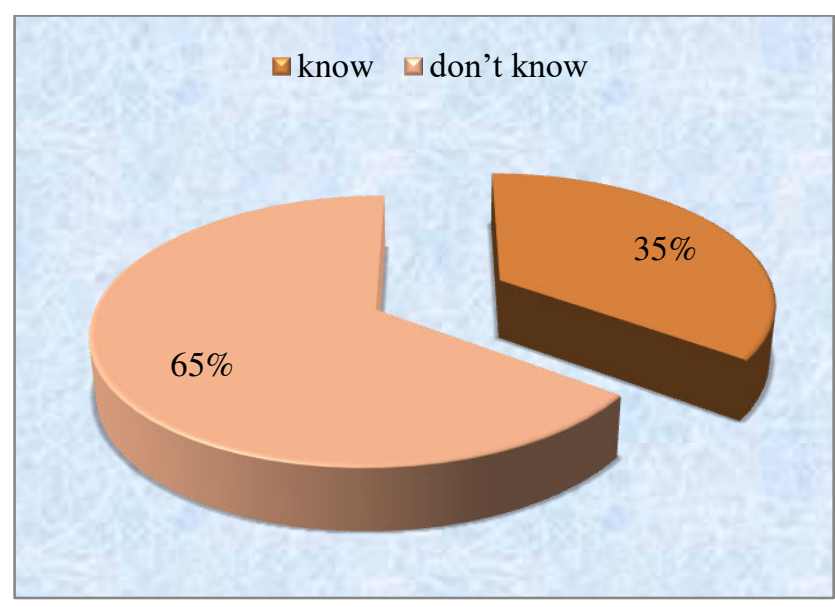

Fig 4: Parents concern about "Child labor Act."

According to Fig 2, it is observed that most parents consider television as a mass media. Some are consider print media, cinema, radio, internet, mobile phone, billboard as mass media. It is observed from the table that maximum parents consider television as the media in our study. Table 4 reveals that most parents (58.89) are disagree that media plays a significant preamble to generate social awareness, $16.67 \%$ are neutral. Maximum parents are involved in job therefore they no longer have time to watch the role of media and also, they are illiterate. Fig 3; found that most respondents think that mass media can play a significant role to stop child labor and rarely parents don't think so. Also, the media has arrived in the rural areas.

According to Table 5, it is observed that maximum guardians are neutral that the role of the media in stopping child labor is satisfactory. Some parents are not satisfied with the current role of media. The study explored that maximum parents are slightly agree that the role of media in stopping child labor is satisfactory. It can be noticed that most parents 
watched the Bangladeshi movie channel. However, most social awareness programs are mainly broadcast on the government channels (Table 6). Fig 4 explored that maximum parents in Bangladesh don't know about the "Child labor Act" Bangladesh in our survey. They have no idea about this act. So child labor is rising every day.

\section{CONCLUSION:}

The study was drawn the following findings that from both our preliminary result and the result from our model in achieving our objectives; Male children are mostly engaged in child labor than female children in our study. It is observed that most working children's age lies between 12-17 years. It is explored that, most fathers doing small businesses such as they are hawkers; they have small shops. Some are farmers, daily workers and some are unoccupied. It is explored that the maximum number of father's income is very poor. It is very difficult to meet their initial needs with this income. Study also found that big family, uneducated parents are also the reasons for child labor. It has been found that most of the poor parents in Bangladesh are not aware of the "child labor act" in Bangladesh. It is found that most parents are slightly agree that media plays a significant role to raise social awareness.

\section{Recommendation}

- Awareness needs to be raised and parents should focus on educating their children.

- Child Labor act should be strictly enforced.

- Whenever a child labor issue arises the media can provide coverage.

- Establish a dedicated media association for the boycott of child labor.

- Sensitize specific groups to the risks of child labor.

- Embolden the government to address the causes of child labor.

- Create greater public awareness to the risks of child labor.

- Encourage NGOs working in child labor to specific actions.

UniversePG I www.universepg.com

\section{ACKNOWLEDGEMENT:}

This project was supported by Comilla University, Bangladesh Research Grant for FY (2019-20), on "Impact of Mass Media to Creates Awareness among the Poor Parents against Child Labor" and provided to Md. Farhad Hossain.

\section{CONFLICT OF INTERESTS:}

The author declared no conflicts of interest concerning the present research work.

\section{REFERENCES:}

1) Bangladesh Bureau of Statistics. (2006). Baseline Survey for Determining Hazardous Child Labour Sectors in Bangladesh 2005. Dhaka: Government of the People's Republic of Bangladesh. ISBN 978-9845086257. https://www.slideshare.net/lelinahmed/childlabour-in-bangladesh-59274052

2) Bequele, Assefa; Jo Boyden (eds.). (1988). Combating Child Labor. Geneva: ILO, Pp. 226.

https://journals.sagepub.com/doi/abs/10.1177/00 2087289003300312

3) Brawley E. (1995). Human Services and the Media, Harwood Academic Publisher, Australia.

4) Goddard, C. \& Saunders, B. J. (2000). "The role of the media", in Project Axis-Child Sexual Abuse in Queensland: Selected Research Papers, Queensland Crime Commission, Brisbane.

5) Hossain MF, Nandi DC, and Uddin KMK. (2020). Prediction of banking sectors financial data of Dhaka stock exchange using Autoregressive Integrated Moving Average (ARIMA) approach, Int. J. Mat. Math. Sci., 2(4), 64-70.

https://doi.org/10.34104/ijmms.020.064070

6) Jensen, P. \& Nielsen, H. S. (1997). Child labor or school attendance? Evidence from Zambia. Journal of Population Economics, 10(4), 407-424.

https://link.springer.com/article/10.1007/s00148 $\underline{0050051}$

7) National Child Labour Survey (NCLS), (2013). Bangladesh Bureau of Statistics with 
support from the International Labour Organization (ILO), October 2015. https://www.ilo.org/ipec/Informationresources/ WCMS IPEC PUB 28175/lang--en/index.htm

8) Paul, T. (2008). Child Labour- Prohibition v. abolition: untangling the constitutional tangle. Journal of Indian. P.143

9) Schmitz, C.L., Traver, E. K., Larson, D. (2004). Child Labor: A Global View. Westport, Connecticut: Greenwood Press, Pp.1-2. ISBN 978-0-313-32277-8

10) Sultana T. (2020). Labor demand and exportoriented industrialization of Bangladesh, Asian J. Soc. Sci. Leg. Stud., 2(6), 115-121. https://doi.org/10.34104/ajssls.020.01150121

11) The Daily Star, (2011). No to domestic help under-12, February 16, [online]. Retrieved from:

http://www.thedailystar.net/newDesign/newsdetails.php?nid=174411
12) UNICEF, ILO, World Bank Group, (2009). Understanding Children's Work in Bangladesh, June 2009 (unpublished) [online].

Available at:

http://www.unicef.org/bangladesh/Child labour. pdf.

13) UNICEF, (2012). "Percentage of children aged 5-14 engaged in child labor".

14) UNICEF, (2010). "To eliminate child labor, "attack it at its roots," UNICEF says".

15) UNESCO, (2019). Institute for Statistics. Gross intake ratio to the last grade of primary education, both sexes (\%). Accessed March 16, 2019. For more information, please see "Children's Work and Education Statistics: Sources and Definitions" in the Reference Materials section of this report. http://data.uis.unesco.org/

Citation: Hossain MF. (2020). Impact of mass media to creates awareness among the poor parents against child labor, Asian J. Soc. Sci. Leg. Stud., 2(6), 122-128. https://doi.org/10.34104/ajssls.020.01220128 @) 